\title{
Crystallinity and microchemistry of Nassarius reticulatus (Caenogastropoda) statoliths: Towards their structure stability and homogeneity
}

\author{
Susana Galante-Oliveira ${ }^{\text {a,*}}$, Raquel Marçal ${ }^{a}$, Fernanda Guimarães ${ }^{b}$, Jorge Soares ${ }^{c}$, José Carlos Lopes ${ }^{\text {, }}$ \\ Jorge Machado ${ }^{\mathrm{d}}$, Carlos Barroso ${ }^{\mathrm{a}}$ \\ a Biology Department E' CESAM, University of Aveiro, Campus Universitário de Santiago, 3810-193 Aveiro, Portugal \\ ${ }^{\mathrm{b}}$ Unit of Science and Mineral Technology, National Laboratory of Energy and Geology (LNEG), Rua da Amieira, Apart. 1089, 4466-901 S. Mamede de Infesta, Portugal \\ ${ }^{\mathrm{C}}$ Department of Physics \& I3N, University of Aveiro, Campus Universitário de Santiago, 3810-193 Aveiro, Portugal \\ ${ }^{\mathrm{d}}$ Laboratory of Applied Physiology, Department of Aquatic Production, Institute of Biomedical Sciences Abel Salazar (ICBAS), University of Porto, Rua de Jorge Viterbo Ferreira \\ 228, 4050-313 Porto, Portugal
}

\section{A R T I C L E I N F O}

\section{Article history:}

Received 5 November 2013

Received in revised form 30 March 2014

Accepted 31 March 2014

Available online 5 April 2014

\section{Keywords}

Statoparticles

Statolith

Gastropoda

Microchemistry

Micro Raman spectroscopy

Electron microprobe analysis

\begin{abstract}
A B S T R A C T
Gastropod statoliths are spherical biocarbonates formed during their lifespan. The stability and homogeneity of these structures' mineral matrix was characterised along their radiuses, using Nassarius reticulatus as a model. Generally, they were proved to be bimineralic. Two of the three $\mathrm{CaCO}_{3}$ Crystalline polymorphs occurring in biocarbonates - aragonite and calcite - coexist along statolith radiuses, aragonite being unequivocally the most abundant phase. The presence of a diffuse organic matrix was also perceived by the detection of a weak Raman band between 2800 and $3000 \mathrm{~cm}^{-1}$ consistently observed along radiuses. Beyond the apparent stability and homogeneity, different crystalline orientations were disclosed by Raman spectroscopy. A change in the intensity pattern of the features related to the lattice and bending modes of aragonite between different radiuses give new insights for a possible spherulitic-like growth of these structures. As expected from the relative homogeneity of both mineral and organic signals, there was no pattern on the distribution of $\mathrm{Ca}, \mathrm{O}, \mathrm{Na}$ and $\mathrm{S}$ along radiuses. However, a higher concentration of $\mathrm{Sr}$ occurs in growth rings (known as winter tags), corroborating the already described negative correlation between the concentration of this element in statoliths and temperature. Despite the apparent stability and homogeneity of the matrix during its lifespan, the periodic distribution of Sr potentially influences a dissimilar incorporation of trace elements in increments and growth rings. Since gastropod statolith elemental fingerprinting was recently suggested as a new tool to monitor marine environmental changes, the pressing need for further studies on the incorporation of traces in these structures is highlighted.
\end{abstract}

(c) 2014 Elsevier Inc. All rights reserved.

\section{Introduction}

Statoparticles are biogenic calcified structures located inside most invertebrates' gravireceptors - the statocysts. Their displacement inside the statocysts, owing to the animal's motion, stimulates local sensory cells indicating the body's position in respect to gravity (Chase, 2002), and thus involved in the mechanisms of balance and spatial orientation.

Statoparticles are diverse amongst class Gastropoda, namely regarding type (i.e. multiple statoconia vs. single statolith), shape

\footnotetext{
* Corresponding author. Fax: +351 234372587.

E-mail address: susana.oliveira@ua.pt (S. Galante-Oliveira).
}

and microstructure. These features have been addressed over time, mainly as part of studies on the structure (e.g. Chia et al., 1981; Gao and Wiederhold, 1997; Gorgiladze et al., 2010; McKee and Wiederhold, 1974), development (e.g. D’Asaro, 1965; Gao et al., 1997; Salley, 1986; Wiederhold et al., 1990) and function (e.g. Gallin and Wiederhold, 1977; McKee and Wiederhold, 1974; Wiederhold et al., 1989) of gastropod statocysts. However, the scenario is different as regards to their chemical composition. Hardly any reports on gastropods can be found in the literature and those available refer to a minority of species: statoconia in Helix lucorum (Gorgiladze, 2002) and Aplysia californica (Pedrozo et al., 1997; Wiederhold et al., 1989); statoliths of larvae in Lobatus gigas (Salley, 1986), Concholepas concholepas (Manríquez et al., 